\title{
Simulation-based training in ultrasound - where are we now?
}

\author{
Simulationsbasiertes Training im Ultraschall - wo stehen wir?
}

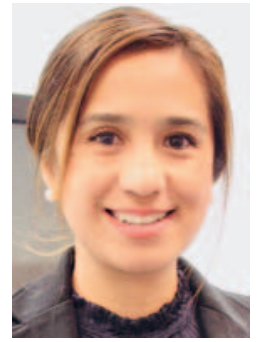

Leizl Joy Nayahangan

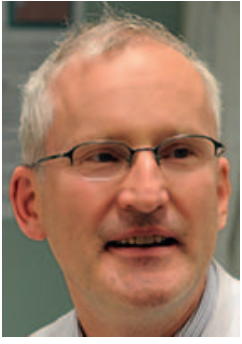

Christoph F. Dietrich

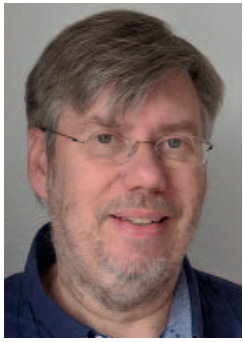

Michael Bachmann Nielsen
Correspondence

Leizl Joy Nayahangan

CAMES Rigshospitalet, Ryesgade 53B (4th Floor), Copenhagen, Denmark

leizl.joy.nayahangan@regionh.dk
Bibliography

Ultraschall in Med 2021; 42: 240-244

DOI 10.1055/a-1352-5944

ISSN $0172-4614$

(C) 2021. Thieme. All rights reserved.

Georg Thieme Verlag KG, Rüdigerstraße 14,

70469 Stuttgart, Germany
The concept and use of simulation in medical education is garnering increasing support from the different specialties in response to the continuous efforts to mitigate preventable errors and promote patient safety. Duty hour reforms that led to reduction of the number of work hours in residency training has also motivated the call to establish other training paradigms to equip junior doctors with the skills and competences to provide quality patient care [1]. There is ample evidence to support the value proposition of simulation. Several studies have shown simulation to be an effective and valuable educational intervention both for training and assessment; and its efficacy in regard to transfer from the training laboratory to the clinical environment has been explored including its impact on patient outcomes [2-4]. Radiology is not averse to simulation-based training. In recent years, simulationbased education has been adapted by the field and is used extensively providing low-risk and immersive training opportunities for radiology trainees to acquire basic and advanced technical skills [5]. Several simulation-based training programs such as basic ultrasound (US), US-guided interventions, interpretation skills, professionalism, and team training have been incorporated in the pre-graduate and post-graduation medical education curricula [5]. The need to develop simulation-based training programs for different ultrasound-guided procedures has been exemplified in a Europe-wide needs assessment that aimed to investigate the training needs of radiology residents [6]. This needs assessment process involved key opinion leaders from different European countries who identified and achieved consensus on 26 procedures for simulation. Ultrasound procedures were highly ranked such as basic skills (i. e. probe handling), abdominal ultrasound; and ultrasound of kidneys, retroperitoneum, intestines, and scrotum. The next step is to develop simulation-based training programs based on these identified needs and to align to the vision of harmonizing training and education of radiologists across Europe as advocated by the European Society of Radiology (ESR) [7].

\section{Where are we now?}

Appropriately trained staff is a high priority to ensure quality of ultrasound diagnostics. This has been underlined by the European Federation of Societies for Ultrasound in Medicine and Biology (EFSUMB) in the recent guidelines, recommending that ultrasound procedures are practiced using simulation equipment to achieve the skills and competences before performing ultrasound procedures on patients [8].

In undergraduate medical education, hands-on training of basic ultrasound skills such i. e. knobology as well as interpretation of images with focus on anatomy and structure definition, has been incorporated into the medical school curriculum [9-11]. However, a recent survey to explore the inclusion of ultrasound training in student medical education reported that despite the increasing use of ultrasound, its integration is slow with only a minority of the European universities surveyed integrating this program into the pre-clinical curricula [12].

This remains true in postgraduate radiology education. There is a paucity on the availability of structured simulation-based 
training programs in ultrasound that are part of the residency curricula. The systematic review by Østergaard et al. in 2015 provided an overview of the simulation-based training opportunities for abdominal ultrasound including their effect. The seventeen studies that were included were heterogenous in the choice of simulation equipment, target participants and outcome measures [13]. Similarly, a systematic review exploring the evidence supporting simulation-based training of percutaneous abdominal and thoracic US-guided procedures reported that majority of the 42 included studies favoured simulation-based training over other educational interventions. However, the quality of evidence for these studies was low and insufficient [14].

The structured approach to developing training programs including gathering evidence for its efficacy is paramount to achieving our goals. In our local setting in Denmark, three simulation-based training programs were developed based on a Danish needs assessment we performed in 2017 [15]. From the list of thirteen identified technical procedures, simulation-based training programs in basic abdominal ultrasound, interventional ultrasound of the kidneys (renal biopsy and nephrostomy), and Focused Assessment with Sonography in Trauma (FAST) are now offered at the local simulation center in Copenhagen for radiology residents [16].

\section{Need for structured and evidence-based training programs}

The optimal development of simulation-based training programs remains a challenge amongst educators. Most often than not, training programs rely on the availability of simulation equipment. To attain the overall goal of simulation, robust training programs should be developed systematically. There are many frameworks in medical education that can be used to ensure focused curricular development, one of which is a six-step approach that starts with establishing the current training needs, defining the goals and objectives including plans for assessment, educational strategies or modalities, implementation processes and evaluation of the training program [17]. A general needs assessment has already been performed, providing radiology educators a guide on what procedures to develop as training programs depending on the needs in their local setting. There is a wide array of simulation-based ultrasound equipment in the market, from simple part-task trainers to virtual reality simulators. The selection of equipment should not depend on its fidelity (how close it resembles reality) but on the goals and objectives of the training program, the target learners and the educational context. Masterylearning coupled with deliberate practice is increasingly promoted as an excellent driver to achieve powerful educational outcomesin terms of knowledge, skills and professionalism competencies [18]. This framework is independent of specified training time, recognizing that each individual learns at his or her own pace. In addition to simulation being an excellent training ground, it also provides the standardized environment that is needed for assessment. Formative assessment such as providing feedback during training and high stakes summative assessment and certification are important aspects of training to ensure that the set educa- tional goals and objectives are achieved. True to a known adage in education, assessment truly is the engine that drives learning. Assessment instruments in ultrasound education are a plenty, however only very few assessment tools have evidence of validity. A valid and reliable assessment tool to evaluate ultrasound competences to determine readiness for practice is the Objective Structured Assessment of Ultrasound Skills (OSAUS) [19]. The OSAUS was used in a randomized controlled trial to measure the effect of a simulation-based mastery training program in abdominal diagnostic ultrasound on clinical performance of radiology trainees [20]. Additionally, a recent study presented a generic and objective tool for assessing competences in percutaneous ultrasound-guided procedure, which resulted from a group consensus process initiated amongst key leaders in the field. The Interventional Ultrasound Skills Evaluation (IUSE) tool covers pre-procedural planning, procedural technique, patient safety, communication, and teamwork [21].

\section{Wide implementation of simulation-based training in ultrasonography}

There is no longer any doubt that simulation is an effective tool in the attainment of skills and competences. We are well beyond this question. We need to shift our focus to how we can optimize its wide implementation to cater to the needs of new clinicians. The efficient implementation of simulation-based training and its integration into the residency curricula remains a challenge despite its increasing availability and use [22]. We continue to encourage the different educational stakeholders to advocate for the development of structured simulation-based training programs for both diagnostic and interventional ultrasound. At current, the World Federation for Ultrasound in Medicine and Biology (WFUMB) is preparing a position paper on the utility of simulators worldwide in collaboration with the European Federation of Societies for Ultrasound in Medicine and Biology (EFSUMB) and several experts in Europe. The next step towards achieving a harmonized ultrasound-training curriculum is to map out current simulation-based training opportunities across the different countries, to identify barriers and facilitators to implementation and to establish systems and standards to optimize the education of future radiologists in the use of ultrasound. We aim for the wide implementation of simulation-based education in ultrasonography and the continuous assurance of evidence-based training programs both in undergraduate and postgraduate radiology education.

\section{Simulationsbasiertes Training im Ultraschall - wo stehen wir?}

In der medizinischen Ausbildung bekommt das Prinzip der Simulation und dessen Anwendung von den verschiedenen Fachbereichen zunehmend Unterstützung im Bemühen, vermeidbaren Fehlern entgegenzuwirken und die Patientensicherheit zu fördern. Dienstzeitreformen, die zur Reduzierung der Arbeitsstunden in der Facharztausbildung führten, regten die Einführung anderer Ausbildungsmodelle an, um junge Ärzte mit Fähigkeiten und 
Kompetenzen auszustatten, die sie für eine qualitativ hochwertige Patientenversorgung benötigen [1]. Die Evidenz für den Nutzen der Simulation ist hinreichend. Mehrere Studien haben gezeigt, dass die Simulation eine effektive und wertvolle Ausbildungsmaßnahme ist, sowohl für das Training als auch für die Beurteilung. Ihre Leistungsfähigkeit bezüglich des Transfers vom Trainingsumfeld in die klinische Praxis wurde untersucht, auch im Hinblick auf das Outcome der Patienten [2-4]. Die Radiologie ist dem simulationsbasierten Training nicht abgeneigt. In den letzten Jahren wurde die simulationsbasierte Ausbildung dem Fachgebiet angepasst und wird ausgiebig genutzt, um den Auszubildenden in der Radiologie risikoarme und umfassende Schulungsmöglichkeiten zum Erwerb grundlegender und fortgeschrittener technischer Fertigkeiten zu bieten [5]. Mehrere simulationsbasierte Schulungsprogramme, wie z. B. Basis-Ultraschall (US), US-geführte Interventionen, Interpretationsfähigkeiten, Professionalität und Teamtraining, wurden in die Curricula der prä- und postgraduellen medizinischen Ausbildung aufgenommen [5]. Die Notwendigkeit, simulationsbasierte Schulungsprogramme für verschiedene ultraschallgestützte Verfahren zu entwickeln, zeigte beispielhaft eine europaweite Bedarfsanalyse, deren Ziel es war, den Trainingsbedarf von Assistenzärzten der Radiologie zu untersuchen [6]. An dieser Bedarfsanalyse waren wichtige Meinungsführer aus verschiedenen europäischen Ländern beteiligt, die bei den 26 identifizierten Simulationsverfahren einen Konsens erzielten. Als hoch bewertet wurden Ultraschallmethoden wie etwa Basiskompetenzen (d. h. „Handling“ des Schallkopfes), abdomineller Ultraschall und Sonografie der Nieren, des Retroperitoneums, des Darms und des Skrotums. Der nächste Schritt besteht darin, simulationsbasierte Trainingsprogramme auf Basis dieses ermittelten Bedarfs zu entwickeln und sich an der Vision der Harmonisierung der Ausund Weiterbildung von Radiologen in ganz Europa auszurichten, wie es die ESR („European Society of Radiology“) befürwortet [7].

\section{Wo stehen wir?}

Entsprechend geschulte Anwender stehen an erster Stelle, wenn es darum geht, die Qualität in der Ultraschalldiagnostik sicherzustellen. Dies wurde von der EFSUMB („European Federation of Societies for Ultrasound in Medicine and Biology“) in den jüngsten Leitlinien hervorgehoben. Sie empfehlen, dass Ultraschalltechniken an Simulatoren praktisch geübt werden, um Fähigkeiten und Kompetenzen zu erwerben, ehe diese Verfahren am Patienten angewandt werden [8].

In der medizinischen Grundausbildung wurden praktische Übungen von grundlegenden Ultraschallfähigkeiten, wie z. B. die „Knopfologie“ sowie die Interpretation von Bildern mit Schwerpunkt auf Anatomie und Definition von Strukturen, in das Curriculum der medizinischen Fakultäten aufgenommen [9-11]. Eine kürzlich durchgeführte Umfrage zur Einbeziehung des Ultraschalltrainings in die studentische medizinische Ausbildung zeigte, dass die Integration der Sonografie trotz zunehmender Anwendung nur langsam erfolgt und nur sehr wenige der befragten europäischen Universitäten ein solches Programm in das vorklinische Curriculum eingebaut haben [12].
Dies gilt ebenso für die postgraduelle Ausbildung in der Radiologie. Es gibt nur sehr wenige strukturierte simulationsbasierte Ultraschallschulungen, die Bestandteil im Curriculum der Weiterbildung zum Facharzt sind. Der systematische Review von Østergaard et al. 2015 gab einen Überblick über Möglichkeiten einer simulationsbasierten Schulung im abdominellen Ultraschall einschließlich dessen Auswirkung. Die 17 eingeschlossenen Studien waren heterogen bezüglich der Simulator-Apparaturen, der Teilnehmer und der Ergebnisparameter [13]. Ähnliches berichtet ein systematischer Review, der die Evidenz eines simulationsbasierten Trainings bei US-geführten perkutanen abdominalen und thorakalen Interventionen untersuchte. In den meisten der 42 eingeschlossenen Studien wurde das simulationsbasierte Training gegenüber anderen Schulungsmaßnahmen bevorzugt. Allerdings war die Qualität der Evidenz in diesen Studien gering und unzureichend [14].

Für das Erreichen unserer Ziele ist von größter Bedeutung, dass ein strukturierter Ansatz bei der Entwicklung von Schulungskonzepten verfolgt wird, einschließlich der evidenzbasierten Ermittlung ihrer Effizienz. In unserem lokalen Umfeld in Dänemark wurden 3 simulationsbasierte Schulungsprogramme auf Grundlage einer dänischen Bedarfsanalyse entwickelt, die wir 2017 durchgeführt haben [15]. Aus der Liste der 13 identifizierten Verfahren werden nun simulationsbasierte Schulungsprogramme für abdominalen Basis-Ultraschall, interventionellen Ultraschall der Nieren (Nierenbiopsie und Nephrostomie) und FAST („Focused Assessment with Sonography in Trauma“) im lokalen Simulationszentrum in Kopenhagen für Assistenzärzte der Radiologie angeboten [16].

\section{Bedarf an strukturierten und evidenzbasierten Schulungsprogrammen}

Die optimale Entwicklung von simulationsbasierten Trainingsprogrammen bleibt eine Herausforderung für die Ausbilder. Oftmals sind die Schulungsprogramme von der Verfügbarkeit von Simulatoren abhängig. Um das Hauptziel der Simulation zu erreichen, sollten Trainingsprogramme systematisch entwickelt werden. Es gibt viele Rahmenbedingungen in der medizinischen Ausbildung, die genutzt werden können, um eine fokussierte Lehrplanentwicklung zu gewährleisten. Eine davon ist ein 6-stufiger Ansatz, der mit der Ermittlung des aktuellen Ausbildungsbedarfs beginnt und Ziele und Vorgaben definiert, einschließlich der Pläne für die Beurteilung, der Ausbildungsstrategien oder -modalitäten, der Umsetzungsprozesse und der Evaluierung des Schulungsprogramms [17]. Es wurde bereits eine allgemeine Bedarfsanalyse durchgeführt, die den Ausbildern in der Radiologie einen Leitfaden dafür bietet, welche Verfahren als Schulungsprogramme je nach den Bedürfnissen ihres lokalen Umfelds zu entwickeln sind. Es gibt eine große Auswahl an simulationsbasierten Ultraschallgeräten auf dem Markt, von einfachen Teilaufgabentrainern bis hin zu Virtual-Reality-Simulatoren. Die Wahl der Ausrüstung sollte nicht von ihrer Wiedergabetreue abhängen (wie sehr sie der Realität ähnelt), sondern von den Zielen des Schulungsprogramms, den anvisierten Lernenden und dem Ausbildungskontext. Mastery Learning, gekoppelt mit bewusster Praxis, wird zunehmend geför- 
dert, da es eine ausgezeichnete Antriebskraft darstellt, um leistungsstarke Lernerfolge in Bezug auf Wissen, Fertigkeiten und Professionalität zu erreichen [18]. Dieser Rahmen ist unabhängig von einer vorgegebenen Übungszeit und erkennt an, dass jeder Einzelne in seinem eigenen Tempo lernt. Die Simulation ist nicht nur ein hervorragendes Übungsfeld, sondern bietet auch die standardisierte Umgebung, die für die Beurteilung benötigt wird. Eine formative Bewertung, wie z. B. Feedback während des Trainings, und hohe Anforderung an die summative Bewertung und Zertifizierung sind wichtige Trainingsaspekte, um sicherzustellen, dass die gesetzten Ausbildungsziele und -vorgaben erreicht werden. Bekannterweise ist Feedback einer der „wirkungsmächtigsten Einflussfaktoren“ auf das Lernen. Es gibt sehr viele Instrumente der Bewertung in der Ultraschallausbildung, aber nur wenige davon haben sich als valide erwiesen. Ein wertvolles und zuverlässiges Instrument, um Ultraschallkompetenzen im Hinblick auf die Fähigkeit zur praktischen Umsetzung zu bewerten, ist die OSAUS („Objective Structured Assessment of Ultrasound Skills“) -Skala [19]. OSAUS wurde in einer randomisierten, kontrollierten Studie verwendet, um bei Auszubildenden in der Radiologie den Effekt eines simulationsbasierten Mastery-Trainingsprogramms im abdominalen diagnostischen Ultraschall auf die klinische Umsetzung zu bestimmen [20]. Darüber hinaus wurde in einer kürzlich durchgeführten Studie eine allgemeine und objektive Methode zur Bewertung der Kompetenzen bei perkutanen ultraschallgesteuerten Verfahren vorgestellt, das - initiiert durch die wichtigsten Führungskräfte auf diesem Gebiet - aus dem Konsensusprozess der Gruppe hervorgegangen ist. Das IUSE („Interventional Ultrasound Skills Evaluation“) -Tool umfasst die Planung vor dem Eingriff, die Arbeitstechnik, die Patientensicherheit, die Kommunikation und die Teamarbeit [21].

\section{Breite Implementierung des simulations- basierten Trainings in der Sonografie}

Es besteht kein Zweifel mehr daran, dass Simulatoren ein effektives Instrument zum Erwerb von Fähigkeiten und Kompetenzen darstellen. Wir sind weit über diese Frage hinaus. Wir müssen uns darauf konzentrieren, wie wir die breite Umsetzung optimieren können, um den Bedürfnissen zukünftiger Kliniker gerecht zu werden. Die effiziente Implementierung des simulationsbasierten Trainings und dessen Einbindung in die Curricula der Facharztausbildung bleiben herausfordernd, trotz zunehmender Verfügbarkeit und Nutzung [22]. Wir ermutigen die verschiedenen Akteure im Ausbildungsbereich weiterhin, sich für die Entwicklung strukturierter simulationsbasierter Ausbildungskonzepte sowohl für den diagnostischen als auch für den interventionellen Ultraschall einzusetzen. Derzeit bereitet die WFUMB („World Federation for Ultrasound in Medicine and Biology“) ein Positionspapier über den Nutzen von Simulatoren weltweit vor, dies in Zusammenarbeit mit der EFSUMB („European Federation of Societies for Ultrasound in Medicine and Biology“) und mehreren Experten in Europa. Der nächste Schritt auf dem Weg zu einem harmonisierten Ultraschall-Ausbildungscurriculum besteht darin, die aktuellen simulationsbasierten Schulungsmöglichkeiten in den verschiedenen Ländern zu erfassen, Hindernisse und Erleichterungen bei der Umsetzung zu identifizieren und Systeme und Standards festzulegen, um die Ausbildung zukünftiger Radiologen in der Anwendung von Ultraschall zu optimieren. Unser Ziel ist die breite Implementierung der simulationsbasierten Ausbildung in der Ultraschallsonografie und die kontinuierliche Sicherstellung von evidenzbasierten Ausbildungskonzepten in der Radiologie sowohl in der studentischen Grundausbildung als auch in der postgraduellen Weiterbildung.

\section{Conflict of Interest}

The authors declare that they have no conflict of interest.

\section{References}

[1] Johns MM, Wolman DM, Ulmer C. Resident duty hours: enhancing sleep, supervision, and safety; 2009

[2] Cook DA, Hatala R, Brydges R et al. Technology-enhanced simulation for health professions education: a systematic review and meta-analysis. Jama 2011; 306: 978-988

[3] McGaghie WC, Issenberg SB, Cohen MER et al. Does simulation-based medical education with deliberate practice yield better results than traditional clinical education? A meta-analytic comparative review of the evidence. Academic medicine: journal of the Association of American Medical Colleges 2011; 86: 706

[4] Issenberg SB, McGaghie WC, Hart IR et al. Simulation technology for health care professional skills training and assessment. Jama 1999; 282 : 861-866

[5] Chetlen AL, Mendiratta-Lala M, Probyn L et al. Conventional Medical Education and the History of Simulation in Radiology. Academic radiology 2015; 22: 1252-1267

[6] Nayahangan LJ, Albrecht-Beste E, Konge L et al. Consensus on technical procedures in radiology to include in simulation-based training for residents: a European-wide needs assessment. European radiology 2021; 31: $171-180$

[7] (ESR) ESoR. Renewed ESR advocacy for the harmonisation of the radiology profession. May 2019. https://www.myesr.org/article/2532; accessed 22 November 2019

[8] Lorentzen T, Nolsøe C, Ewertsen C et al. EFSUMB Guidelines on Interventional Ultrasound (INVUS), part I-general aspects (long version). Ultraschall in der Medizin-European Journal of Ultrasound 2015; 36 : E1-E14

[9] Jamniczky HA, McLaughlin K, Kaminska ME et al. Cognitive load imposed by knobology may adversely affect learners' perception of utility in using ultrasonography to learn physical examination skills, but not anatomy. Anat Sci Educ 2015; 8: 197-204

[10] Shah S, Tohmasi S, Frisch E et al. A comparison of simulation versus didactics for teaching ultrasound to Swiss medical students. World journal of emergency medicine 2019; 10: 169

[11] Bahner DP, Adkins E], Hughes D et al. Integrated medical school ultrasound: development of an ultrasound vertical curriculum. Critical ultrasound journal 2013; 5: 1-9

[12] Prosch H, Radzina M, Dietrich CF et al. Ultrasound Curricula of Student Education in Europe: Summary of the Experience. Ultrasound international open 2020; 6: E25-E33

[13] Østergaard ML, Ewertsen C, Konge L et al. Simulation-Based Abdominal Ultrasound Training - A Systematic Review. Ultraschall in der Medizin (Stuttgart, Germany: 1980) 2016; 37: 253-261

[14] Kahr Rasmussen N, Andersen TT, Carlsen J et al. Simulation-Based Training of Ultrasound-Guided Procedures in Radiology - A Systematic 
Review. Ultraschall in der Medizin (Stuttgart, Germany: 1980) 2019; 40 : 584-602

[15] Nayahangan LJ, Nielsen KR, Albrecht-Beste E et al. Determining procedures for simulation-based training in radiology: a nationwide needs assessment. European radiology 2018; 28: 2319-2327

[16] Copenhagen Academy for Medical education and Simulation (CAMES). https://www.regionh.dk/CAMES/Traening-og-undervisning/Kurser-forLaeger/Sider/default.aspx

[17] Thomas PA, Kern DE, Hughes MT et al. Curriculum development for medical education: a six-step approach; JHU Press; 2016

[18] McGaghie WC, Issenberg SB, Barsuk JH et al. A critical review of simulation-based mastery learning with translational outcomes. Medical education 2014; 48: 375-385
[19] Tolsgaard MG, Ringsted C, Dreisler E et al. Reliable and valid assessment of ultrasound operator competence in obstetrics and gynecology. Ultrasound Obstet Gynecol 2014; 43: 437-443

[20] Ostergaard ML, Rue Nielsen K, Albrecht-Beste E et al. Simulator training improves ultrasound scanning performance on patients: a randomized controlled trial. European radiology 2019; 29: 3210-3218

[21] Kahr Rasmussen N, Nayahangan LJ, Carlsen J et al. Evaluation of competence in ultrasound-guided procedures-a generic assessment tool developed through the Delphi method. European radiology 2020. doi:10.1007/s00330-020-07280-z

[22] Khamis NN, Satava RM, Alnassar SA et al. A stepwise model for simulation-based curriculum development for clinical skills, a modification of the six-step approach. Surgical endoscopy 2016; 30: 279-287 